\title{
Marketing m-services: Establishing a usage benefit typology related to mobile user characteristics
}

Received (in revised form): 23rd March, 2004

\author{
Gillian Sullivan Mort \\ is Associate Professor at Marketing in the Griffith Business School. She is currently Deputy Director of the Services Industry \\ Research Centre at Griffith University. Her research areas include international marketing, social entrepreneurship and \\ m-marketing. Her work has been published in such journals as Journal of Database Marketing \& Customer Strategy \\ Management, Journal of World Business and the Australasian Marketing Journal.

\section{Judy Drennan} \\ is a senior lecturer in the School of Advertising, Marketing and Public Relations at the Queensland University of Technology. \\ She received her PhD from Deakin University in Australia, and has since undertaken research in the areas of small business \\ internet adoption, entrepreneurship, m-marketing and internet sponsorship. Her work has been published in Small Enterprise \\ Research, Journal of Innovation and Entrepreneurship, Journal of Services Marketing, Journal of Database Marketing, Journal \\ of Marketing Management and Journal of Macromarketing.
}

Gillian Sullivan Mort Griffith Business School, Griffith University Gold Coast Campus, Parklands Drive, Southport QLD 4215 , Australia.

Tel: +61 738757111 ; e-mail:

gillian.mort@griffith.edu.au

\begin{abstract}
Despite the relative paucity of knowledge relating to consumer attitudes towards acceptance and use of mobile digital technology, organisations are investing in the technology capabilities to take advantage of the emergent opportunities in mobile marketing (m-marketing). This paper adopts a consumer perspective to increase our understanding of business-to-consumer marketing of ( $\mathrm{m}$-services, defined as both mobile commerce ( $\mathrm{m}$-commerce) transaction messages and information services accessed by mobile devices. Data were collected from a sample of 250 respondents using an online survey and a modified snowball procedure. Results show that consumers perceive mobile services (m-services) in terms of usage benefit types that the authors label 'mobile life enhancers' (MLEs). The research further establishes important patterns of relationships between mobile user characteristics and MLE types. Conclusions are presented and future research directions are discussed.
\end{abstract}

\section{INTRODUCTION}

Rapidly developing technology capabilities and mobile device adoptions have increasingly led to the expectations of a mobile commerce (m-commerce) revolution, similar in scale to the first wave of electronic commerce (e-commerce) experienced in the late 1990s. Indeed sales of handheld devices in the USA alone have risen from US $\$ 1.1$ bn to US $\$ 5.3$ bn (Analytics 2004) ${ }^{1}$ while global projected revenue for m-commerce is predicted to be US $\$ 88 \mathrm{bn}$ by $2009 .^{2}$ While technology capabilities have continued to expand, however, the nexus between business strategies and value capabilities provided by mobile digital technology is not yet fully understood. Fundamental to this understanding is the development of m-marketing ${ }^{3}$ through the examination of m-services consumption and the classification of $\mathrm{m}$-services usage structures and their value for particular mobile users. This paper, therefore, investigates $\mathrm{m}$-services usage and the 
relationship between emergent $m$-services types and mobile user characteristics.

M-services have been defined as any kind of service that can be accessed via a mobile device and which are delivered in interactions between an organisation and a customer. ${ }^{4} \mathrm{M}$-services have also been broadly defined as the delivery of services via mobile devices such as smart phones, mobile phones and personal digital assistants (PDAs). ${ }^{5}$ Services can be delivered to mobile devices via voice applications using vortals, text applications such as short message service (SMS), e-mail (the current I-mode application), and web-mediated delivery using the $3 \mathrm{G}$ spectrum. In an important advance, the concept of m-services has also been used to encompass both $\mathrm{m}$-commerce communication and other informational services — such as consumer notices and alerts that firms may provide - not traditionally covered by $\mathrm{m}$-commerce. ${ }^{6}$ Here a definition of $m$-services that includes both $\mathrm{m}$-commerce transaction messages and information services accessed by mobile devices is adopted.

The paper begins with a review of the literature on mobile services and consumer attitudes and demographics related to adoption and use of new technology. Next, the methodology for this study is described followed by a presentation of an analysis of results. A discussion of the emergent typologies and their link to consumer characteristics follows before the paper concludes with discussion and directions for future research.

\section{LITERATURE REVIEW}

\section{Mobile services value and benefit}

Given that academic study of the $\mathrm{m}$-marketing field is relatively new, the research in this area is pre-paradigmatic.
Research that has been identified thus far is located in three main domains: the role of mobile internet applications for mobile network operators; studies that review technological and market revolutions; and user-centred studies focusing on consumer responses to early product offerings. ${ }^{7}$ The present research is located within the third domain, focusing on consumer responses to existing and emerging m-services.

In understanding consumer responses to product offerings, the value provided is an important construct. Sheth et al. ${ }^{8}$ propose consumer value as a multidimensional phenomenon. Consistent with this approach, Anckar and D'Incau' identify five 'missions/settings' in which mobile value is provided for consumers. These include: time critical needs and arrangements — where immediacy is essential; spontaneous needs and decisions where - no planning is involved; entertainment needs - using 'time filler' as opposed to 'time killer' services; ${ }^{10}$ efficiency needs and ambitions - to increase productivity during 'dead spots' (eg commuting time) of the day; and mobility related needs - where location-based services can be accessed when on the move. Similarly, others ${ }^{11}$ had earlier identified value propositions for $\mathrm{m}$-commerce applications around the values of 'ubiquity', 'convenience', 'localisation' and 'personalisation'. It has also been argued that if customers can access pertinent information specific to a particular place and time, the perceived value of the mobile service will increase. ${ }^{12}$ Moreover, the capacity to provide personalised services via mobile devices presents businesses with opportunities to create strong customer relationships that build loyalty and encourage transactions. ${ }^{13}$ 
In an allied field, researchers have developed a measure to characterise the internet user, ${ }^{14}$ which they labelled the Web Motivation Inventory (WMI). Users were classified by their motives and identified as researching, communicating, surfing and shopping. Although the WMI relates to the web only, characterising user and usage types is an approach that is also applicable in the mobile digital environment and to $\mathrm{m}$-services in particular. In the $\mathrm{m}$-services case, while some research exists that relates interest in to $\mathrm{m}$-services to mobile value, ${ }^{15}$ the authors are not aware of any research that attempts to characterise usage variety patterns (or likelihood of use) of m-services in a similar way to Rodgers and Sheldon. ${ }^{16}$ They suggest that, as with the internet and other new products high in experiential characteristics, ${ }^{17}$ consumers begin to understand the products better after they become more widely available and begin to be used, or in the first instance symbolically adopted. ${ }^{18}$ Ridgeway and Price $^{19}$ investigated use innovativeness and suggested that in many instances consumers take an active role in the production of product lines. They gain an appreciation of value relationships and benefits and adopt patterns of use not initially apparent to the product developers, leading them to organise their perceptions of products and services in meaningful ways, relating to benefits that enhance life activities, interests and pursuits. Carroll ${ }^{20}$ refers to this as the process of technology appropriation. Consistent with the understanding that consumers take an active role in the production of product uses, the authors contend that consumers perceive m-services as heterogeneous rather than homogeneous, and that a clear derived typology will be discernable in the expressed intention to use $\mathrm{m}$-services, given their observations of, experiences with and emergent uses of the new applications. Following Rodgers and Sheldon, ${ }^{21}$ they consider that such a typology will be a useful tool for strategists and practitioners in tailoring m-services to satisfy user needs more effectively: thus, the authors hypothesise that consumers perceive $m$-services as heterogeneous, and differentiate among $\mathrm{m}$-services offerings on the basis of usage benefits (Hypothesis 1).

\section{Consumer characteristics: Values, attitudes and demographics}

Consumer values and attitudes have been found to influence the adoption of technology and technology-related products. The next section develops the hypotheses relating to the association between consumer characteristics and intentions to use m-services, and addresses innovativeness, self-efficacy, love of shopping, interpersonal influence and demographics — specifically gender and age.

\section{Innovators}

Innovativeness has been considered an influential attribute for explaining uptake and use of new technologies. In their study of the motivations of internet shoppers, Donthu and Garcia ${ }^{22}$ found that they were significantly more innovative than non-internet shoppers. Agarwal and Prasad ${ }^{23}$ developed and used the construct of personal innovativeness in the domain of information technology (PITT) to identify those who were likely to use IT innovations earlier than others. Results of their study showed a significant correlation between PITT and usage intentions. Here, it is hypothesised that individuals with an innovative attitude are more likely to have intentions to use m-services (Hypothesis 2a). 


\section{Techno-confidents}

Confidence with technology or perceived self-efficacy is defined as 'beliefs in one's capabilities to mobilise the motivation, cognitive resources, and courses of action needed to meet given situational demands'. ${ }^{24}$ Compeau and Higgins, ${ }^{25}$ who define computer self-efficacy as a 'judgement of one's capability to use a computer, and ... judgements of the ability to apply those skills to broader tasks', found that it plays a significant role in shaping individuals' computer behaviours in terms of use. In the context of mobile phones and m-services mobile self-efficacy, 'judgement of one's capability to use a mobile phone and associated services, and ... judgements of the ability to apply those skills to broader tasks' would be the corresponding construct related to usage of $\mathrm{m}$-services. The present authors hypothesise that techno-confidence and mobile self-efficacy will be associated with intentions to use m-services (Hypothesis $2 b)$.

\section{Shopping lovers}

In their research on internet shopping, Donthu and Garcia ${ }^{26}$ found that a positive attitude towards shopping was not associated with online shopping. Despite their negative findings, the authors suggest that in the mobile environment, shopping lovers - those who receive an emotional gratification from shopping and consider shopping an enjoyable leisure activity ${ }^{27}$ will be more likely to respond positively to the variety and interest presented by the wide range of $\mathrm{m}$-services. Hence, it is hypothesised here that there will be a positive association between shopping lovers and intentions to use $\mathrm{m}$-services (Hypothesis 2c).

\section{Interpersonal Influence}

The role of people in the flow of communication has long been acknowledged. ${ }^{28}$ Moreover, during this communication flow, many are susceptible to interpersonal influence. An early review ${ }^{29}$ concluded that susceptibility to interpersonal influence is a general trait that varies across persons. In addition, a person's relative susceptibility to influence is correlated across a range of social situations. A two-factor, 12 item scale has been developed to measure consumer susceptibility to interpersonal influence. ${ }^{30}$ Those highly susceptible to interpersonal influence are likely to purchase products, services and brands they observe used by others as well as being influenced by personal recommendations and adoption of products by significant others. As mobile devices and services are often used in public and involve participation by others in mobile communication, this trait - the susceptibility to interpersonal influence — is likely to be strongly positively associated with intentions to use m-services (Hypothesis $2 d)$.

\section{Influence of demographics}

Consumer demographics, particularly gender, have also been identified as having an important relationship to the intention to use and actual use of new technology. Past research on internet use has found that, not only are females slower to adopt, but those who do use the internet do so less frequently and for a smaller number of tasks than males. ${ }^{31}$ Other research ${ }^{32}$ found that while there were gender differences in the perceptions of e-mail, no differences in use were shown. More recently, Anckar and D'Incau ${ }^{33}$ investigated gender differences in the willingness to use $\mathrm{m}$-commerce and found that, in four out of five examples where significant 
Table 1: Hypotheses guiding research into used $m$-services

\begin{tabular}{ll}
\hline Hypothesis & Summary \\
\hline 1 & Consumers perceive m-services as heterogeneous, and differentiate among m-services \\
& offerings on the basis of usage benefits. \\
$2 a$ & Innovative attitude will be associated with intentions to use m-services. \\
$2 b$ & Mobile self-efficacy (techno-confidence) will be associated with intentions to use m-services. \\
$2 c$ & Love of shopping will be associated with intentions to use m-services. \\
$2 d$ & Susceptibility to interpersonal influence will be associated with intentions to use m-services. \\
$2 \mathrm{e}$ & Males will express higher intentions to use m-services than females. \\
$2 \mathrm{f}$ & Age will be negatively associated with intentions to use m-services. \\
\hline
\end{tabular}

differences existed, males were more likely to use the application than females. It is therefore hypothesised that males will express higher intentions to use m-services than females (Hypothesis 2e). Results of studies on the impact of age on internet use show that younger people are quicker to adopt technology such as the internet, use it for more hours per day and engage in a wider variety of tasks than older users. ${ }^{34}$ Thus, it is hypothesised that there will be a statistically significant relationship between age and intentions to use m-services (Hypothesis 2f).

\section{Summary}

Building on the previous discussion, the authors present in Table 1 a summary of the hypothesis guiding their research.

\section{METHOD}

\section{The sample}

To undertake this study, a web-based survey was used and a notice was placed in a prominent position on a university school's homepage inviting respondents to access and complete the survey.

E-mail invitations were sent to a number of staff and students, directing them to the website and requesting them to send the invitation to others in a modified snowball sampling procedure. The use of snowballing was appropriate as it enabled the sample frame to be extended beyond a university environment into the general population of $\mathrm{m}$-services users. The operational definition for the sample of this current study was 'consumers with access to the web who use mobile phones'.

It could be argued that this is a type of convenience sample, which may be considered a limitation of the present study. Differences between random and convenience samples in terms of their representativeness, however, are not as great as has often been implied ${ }^{35}$ and one can argue that the sample is appropriate for the purposes of this research. Descriptive statistics of survey respondents show that the sampling method was successful in obtaining a suitable representation of the mobile phone users described in the following section.

A total sample size of 250 mobile phone user respondents was obtained, which is an acceptable size for the type of analysis undertaken. ${ }^{36}$ Respondents were aged from between 17 and 19 years to $40+$ years with 59 per cent being female and 41 per cent male. All respondents had at least a secondary school standard of education. All respondents used mobile phones; 75 per cent reported using them everyday and 14 per cent stated that they were currently connected to the internet via 
Table 2: Attitudinal and value constructs measuring consumer characteristics

\begin{tabular}{lll}
\hline Construct & Scale & Cronbach's alpha* $^{*}$ \\
\hline Innovators & Donthu and Garcia (1999) - modified 49 & 0.75 \\
Techno-confidents & Adapted from Compeau and Higgins (1996) & 0.91 \\
Shopping lovers & Donthu and Garcia (1999) & 0.88 \\
Belonging seekers & Adapted from Bearden, Netemeyer and Teel (1989) & 0.92 \\
Consulters & Adapted from Bearden, Netemeyer and Teel (1989) & 0.73 \\
\hline
\end{tabular}

*Using the data from this sample, all scales show acceptable levels of reliability (Nunnaly, 1978). ${ }^{54}$

their mobile. In addition, 94 per cent of respondents were connected to the internet at home.

\section{Instrument}

The web-based survey was comprised of several sections: the first relating to the likelihood of use of value-added mobile services; the second pertaining to consumer attitudes and values; with a final section on demographics.

Seven-point Likert-type scales were used for all questions. Anchors of 'strongly agree' to 'strongly disagree' were used for the attitudinal and value items, while 'unlikely' and 'likely' anchored the likelihood of use of m-services items. Items assessing the various attitudinal and value constructs were adapted from past research as shown in Table 2. The $\mathrm{m}$-services items were derived from services already available in the global marketplace and those known to be in development at the time the survey was administered. The m-services items were presented in randomised order.

\section{Web-based surveys}

The choice of a web survey for data collection is justified on the basis of its appropriateness for the target sample, its response speed ${ }^{37}$ and automated data collation. ${ }^{38}$ Another advantage is its ability to overcome incomplete and inappropriate responses. Respondents who submitted their survey responses were reminded with a display notifying them of missing questions and directing them to backtrack to complete the missing data and resubmit. Unacceptable responses were avoided by the application of an adapted common gateway interface (CGI) program to detect problems such as out of bounds and inappropriate responses.

In keeping with customary ethical guidelines, the web survey was approved by a university ethics committee and procedures for data integrity, security and anonymity were followed. Informed consent was obtained by presenting the electronic consent form to the respondents, detailing the ethical procedures in place prior to their viewing of the survey and requiring a separate click to signal consent before proceeding to the survey itself.

\section{Analytical process}

All statistical analyses were undertaken using SPSS 11.5 for Windows. The psychometric properties of the administered attitudinal and values scales were examined with scale reliability reported using Cronbach alphas (see Table 2). The Bearden, Netemeyer and Teel scale ${ }^{39}$ formed two meaningful and reliable subscales, one tapping the need to belong (termed Belonging Seekers) and the other the need to consult opinions of reference group members (termed Consulters). Both subscales were retained and each subjected to 
further analysis in investigating

Hypothesis 2d.

A typology of $m$-services was then empirically derived from the total list of 31 mobile service items using principal axis factor analysis with oblim rotation. This method of factor analysis was adopted because it better suits the purpose of the research, 'to understand the latent structure of a set of variables'. ${ }^{40}$ Factor analysis using principal component extraction with varimax rotation was used in the first instance to explore the underlying factor structure of $m$-services by reducing the number of variables. ${ }^{41}$ Results showed six factors with a high number of cross loadings that made interpretation difficult.

Consequently, further analysis was carried out seeking 'simple structure' which is an important criterion for interpretability. ${ }^{42}$ Oblique rotation was adopted to better represent reality, ${ }^{43}$ specifically direct oblim. This subsequent factor analysis identified six related but distinct factors for $\mathrm{m}$-services. The six factors were retained because all represented the desired 'simple structure' with very few cross loadings and related to meaningful constructs. ${ }^{44}$ Then the reliability of each of these derived $\mathrm{m}$-services scales was analysed and reported using Cronbach alpha.

Finally, bivariate correlations between the independent variables (IVs) and the dependent variables (DVs) were examined. In order to test the existence of these relationships, composite variables were created by summing the scores on scale items for each of the IVs (attitudinal and value orientation scales) and the DVs (derived m-services scales). Correlations were undertaken using Pearson's product moment correlations. The use of correlations is justified as providing the clearest link to the data in this stage of exploratory research.

\section{RESULTS}

The following section presents the findings relating to Hypothesis 1.

A six-factor solution resulted from principal component analysis with varimax rotation, with six Eigenvalues greater than one. As discussed, however, the factor cross-loadings made interpretation difficult, so factor analysis using principal axis and oblim rotation was then undertaken, again showing six factors with Eigenvalues greater than one, with 62 per cent of variance explained before rotation. This subsequent rotation showed a clear six-factor structure and is detailed in Table 3. The list of factors follows the order of importance, indicated by the size of sum of squared loadings (SSLs). ${ }^{45}$

For the first factor, items that related to location services received high loadings. Factor 1 is termed the 'locator services' factor. Items loading highly on this factor are 'use

location/map/direction services'; 'use personal locator service (in case missing or injured)'; 'receive weather reports' and 'receive and read news'. This factor represents the m-services benefit groups providing factual information with relevance to the self within the physical and virtual world.

Factor 2 is termed the 'messaging services' factor. Items loading highly on this factor are 'send/receive pictures'; 'send receive SMS'; 'receive calendar /reminder messages'; 'send/receive multimedia messaging service (MMS)'. This factor represents $\mathrm{m}$-services providing messaging and value-added messaging benefits that allow users to enhance their mobile communications capabilities.

Factor 3 is termed the 'sports/entertainment services' factor. Items loading highly on this factor are 'receive sports information'; 'access adult entertainment'; 'place bets online' and 
Table 3: Factor analysis of $\mathrm{m}$-services

\begin{tabular}{|c|c|c|c|c|c|c|}
\hline M-services & $\begin{array}{l}\text { Factor } \\
1\end{array}$ & 2 & 3 & 4 & 5 & 6 \\
\hline \multicolumn{7}{|l|}{ Locator services } \\
\hline Use location/map/directions services & 0.686 & & & & & \\
\hline Use personal locator service (in case missing or injured) & 0.529 & & & & & \\
\hline Receive weather reports & 0.528 & & & & & \\
\hline \multirow{2}{*}{\multicolumn{7}{|c|}{ Communication services }} \\
\hline & & & & & & \\
\hline Send/receive pictures & & -0.670 & & & & \\
\hline Send/receive SMS & & -0.581 & & & & \\
\hline Receive calendar/reminder services & & -0.483 & & & & \\
\hline Send/receive MMS & & -0.374 & & & & \\
\hline \multicolumn{7}{|l|}{ Sports/entertainment services } \\
\hline Receive sports information & & & 0.535 & & & \\
\hline Access adult entertainment & & & 0.525 & & & \\
\hline Place bets online & & & 0.449 & & & \\
\hline Play online games & & & 0.422 & & & \\
\hline \multicolumn{7}{|l|}{ Mobile online 'chat' services } \\
\hline Chat online with strangers & & & & 0.656 & & \\
\hline Send/receive e-mail & & & & 0.437 & & \\
\hline Search for and compare prices of products while shopping & & & & 0.404 & & \\
\hline Listen to/download music & & & & 0.312 & & \\
\hline \multicolumn{7}{|l|}{ Value-added shopping services } \\
\hline Receive shopping coupons & & & & & -0.750 & \\
\hline Receive personalised shopping alerts (of bargains etc) & & & & & -0.715 & \\
\hline Search for/receive product information while shopping & & & & & -0.536 & \\
\hline Book cinema/theatre tickets & & & & & -0.462 & \\
\hline Use routine banking (pay bills etc) & & & & & -0.370 & \\
\hline \multicolumn{7}{|l|}{ Financial services } \\
\hline Use advanced banking services (eg apply for loans) & & & & & & 0.769 \\
\hline Send insurance damage reports & & & & & & 0.699 \\
\hline Take part in online auctions & & & & & & 0.628 \\
\hline Trade stock & & & & & & 0.626 \\
\hline Buy products online & & & & & & 0.519 \\
\hline Book travel tickets & & & & & & 0.427 \\
\hline Make micro-payments in shops or elsewhere & & & & & & 0.398 \\
\hline Remote activation of appliances & & & & & & 0.390 \\
\hline Access and use transaction services & & & & & & 0.389 \\
\hline Use online currency conversion service & & & & & & 0.360 \\
\hline
\end{tabular}

*Negative item loadings result from oblique rotation method

SMS, short message services; MMS, multimedia messaging service

'play online games'. This entertainment usage benefit factor represents m-services high in entertainment value and more specifically adult oriented entertainment and gaming, which enables users to transform their mobile device from a social vehicle to a self-directed hedonic experience tool.

Factor 4 is termed the 'mobile online "chat" services' factor. Items loading highly on this factor are "chat online with strangers'; 'send/receive e-mail'; 'search for and compare prices while shopping'; 'listen to/download music'. This factor represents available online m-services accessed by the mobile device, and indicates the transfer of desktop computer behaviour to the mobile context.

Factor 5 is termed the 'value-added shopping services' factor. Items loading on this factor are 'receive shopping coupons'; 'receive personalised shopping alerts' (of bargains etc); 'search for/receive product information while shopping'; 'book cinema/theatre tickets'; and 'use routine banking services'. This factor represents $m$-services providing enhanced shopping experience benefit.

Factor 6 is termed the 'financial services' factor and represents use of mobile services that enhance efficiency 
Table 4: Derived m-services typology scales - mobile life enhancers

\begin{tabular}{lll}
\hline Scale & Items & Cronbach's alpha* $^{*}$ \\
\hline $\begin{array}{l}\text { Locator/information } \\
\text { services }\end{array}$ & Map location, personal locator, weather reports, news & 0.82 \\
$\begin{array}{l}\text { Communication services } \\
\text { Sports/entertainment } \\
\text { services }\end{array}$ & $\begin{array}{l}\text { Pictures, SMS, calendar/reminder, MMS } \\
\text { Sports info, adult entertainment, place bets online, }\end{array}$ & 0.71 \\
$\begin{array}{l}\text { Mobile online 'chat' } \\
\text { services }\end{array}$ & $\begin{array}{l}\text { Chat online, e-mail, search for and compare prices, listen to/ } \\
\text { Value-added shopping }\end{array}$ & 0.70 \\
services & $\begin{array}{l}\text { Receive shopping coupons, receive personal shopping alerts, } \\
\text { search for and receive product info, book cinema/theatre }\end{array}$ & \\
Financial services & $\begin{array}{l}\text { tickets online, use routine banking } \\
\text { Advanced banking, send insurance damage claims, take }\end{array}$ & 0.90 \\
& $\begin{array}{l}\text { part in online auctions, trade stock, buy products online, } \\
\text { book travel tickets, make micro-payments, remote activation } \\
\text { of appliances, access and use transaction services, use } \\
\text { online currency conversion services }\end{array}$ & \\
\hline
\end{tabular}

*All scales show acceptable levels of reliability (Nunnaly, 1978). ${ }^{55}$

and interaction possibilities with financial service businesses — such as banks, insurance companies, auction agents and stock exchanges - and financial transactions in general. Ten items loaded on this factor. These were 'use advanced banking services' (eg apply for loans); 'send insurance damage reports'; 'take part in online auctions'; 'trade stock'; 'buy products online'; 'book travel tickets'; 'make micro-payments in shops or elsewhere'; 'remote activation of appliances'; 'access and use transaction services' and 'use online currency conversion services'. This factor represents personal and household financial services usage benefits.

The reliability of each of the types (scales) in the derived m-services typology were assessed using Cronbach alpha. Alphas and standardised item alphas were compared for all scales, in no case was there any notable difference indicating that all items in the individual scales possessed comparable variance. In addition, the 'alpha if item deleted' information was examined for all scales. Again, no item deletions were needed indicating that the scales in the m-services typology are robust. The Cronbach alphas for m-services scales are reported in Table 4.
The results of the factor analysis and the reliability of the derived $\mathrm{m}$-services scales support hypothesis 1 and demonstrate that consumers perceive $\mathrm{m}$-services as being heterogeneous and differentiate among $\mathrm{m}$-services offerings on the basis of usage benefits. This results in six usage benefit types that the authors label 'mobile life enhancers' (MLEs). This label has been applied to depict the way that consumers incorporate $\mathrm{m}$-services offerings into their personal world to enhance their lives.

Results of bivariate correlations between IVs (consumer characteristcs) and the DVS (MLEs) using Pearson's product moment correlations are presented in Table 5. These results indicate important patterns of relationships between the consumer characteristics and MLEs.

The following section presents the findings relating to Hypotheses $2 \mathrm{a}-\mathrm{f}$.

\section{Innovators}

A statistically significant relationship was found between consumers high in innovativeness - innovators - and intentions to use all six MLEs. In particular, innovators have strong associations $(p>0.01)$ with 
Table 5: Result of Pearson's correlation between consumer characteristics and MLEs

\begin{tabular}{|c|c|c|c|c|c|}
\hline MLEs & Innovators & $\begin{array}{l}\text { Techno- } \\
\text { confidents }\end{array}$ & $\begin{array}{l}\text { Shopping } \\
\text { lovers }\end{array}$ & $\begin{array}{l}\text { Belonging } \\
\text { seekers }\end{array}$ & Consulters \\
\hline $\begin{array}{l}\text { Locator/ } \\
\text { information services } \\
\text { Map location, personal locator, weather } \\
\text { reports, news }\end{array}$ & $0.241^{\star \star}$ & $0.208^{\star \star}$ & $0.209^{\star \star}$ & $0.208^{\star \star}$ & 0.122 \\
\hline $\begin{array}{l}\text { Communication services } \\
\text { Pictures, SMS, calendar/reminder, MMS }\end{array}$ & $0.298^{\star *}$ & $0.134^{*}$ & $0.334^{\star \star}$ & $0.253^{\star \star}$ & $0.164^{\star \star}$ \\
\hline $\begin{array}{l}\text { Sports/entertainment services } \\
\text { Sports info, adult entertainment, place bets } \\
\text { online, play online games }\end{array}$ & $0.157^{\star}$ & 0.103 & 0.048 & $0.293^{\star *}$ & 0.097 \\
\hline $\begin{array}{l}\text { Mobile online 'chat' services } \\
\text { Chat online, e-mail, search for and compare } \\
\text { prices, listen to/download music }\end{array}$ & $0.237^{\star \star}$ & 0.0780 & $0.227^{\star \star}$ & $0.270^{\star \star}$ & 0.065 \\
\hline $\begin{array}{l}\text { Value-added shopping services } \\
\text { Receive shopping coupons, receive personal } \\
\text { shopping alerts, search for and receive } \\
\text { product info, book cinema/theatre tickets } \\
\text { online, use routine banking }\end{array}$ & $0.212^{*}$ & $0.138^{*}$ & $0.302^{\star \star}$ & $0.256^{\star \star}$ & $0.151^{*}$ \\
\hline $\begin{array}{l}\text { Financial services } \\
\text { Advanced banking, send insurance damage } \\
\text { claims, take part in online auctions, trade } \\
\text { stock, buy products online, book travel } \\
\text { tickets, make micro-payments, remote } \\
\text { activation of appliances, access and use } \\
\text { transaction services, use online currency } \\
\text { conversion services }\end{array}$ & $0.283^{\star *}$ & $0.151^{*}$ & $0.144^{\star}$ & $0.236^{\star *}$ & 0.015 \\
\hline
\end{tabular}

Two-tailed tests: ${ }^{*} p<005 ;{ }^{* *} p<0.01$

locator/information services, communication services, mobile online 'chat' services and financial services.

\section{Techno-confidents}

These are consumers who have high mobile self-efficacy and perceive that they are able to use mobile services effectively. The results show that there is a strong association between this type of consumer and intention to use highly informational $\mathrm{m}$-services such as locator/information services $(p>0.01)$. Techno-confidence is also associated, albeit at a lower level of significance $(p>0.05)$, with use of communication services, value-added shopping services and financial services.

\section{Shopping levers}

A positive relationship was found between this group of consumers (those who have strong positive emotional orientations towards shopping) and intentions to use five MLE types. No statistically significant association was found with sports/entertainment services.

\section{Belonging seekers}

Those consumers who seek a sense of belonging by purchasing the same products and brands that others purchase were found to be strongly associated with intentions to use all MLEs. In view of the high interpersonal reference group influence, it is likely that these consumers will use more $\mathrm{m}$-services in an effort to gain the approval of others. Thus reference group appeals are likely to strongly influence the levels of use of $\mathrm{m}$-services for this group of consumers.

\section{Consulters}

The consumer social orientation captured in the consulters trait is strongly associated $(p>0.01)$ with the use of 
Table 6: Summary of results of hypotheses

\begin{tabular}{|c|c|}
\hline Hypothesis & Results \\
\hline $\begin{array}{l}\text { Hypothesis 1: } \\
\text { Consumers perceive } m \text {-services as heterogeneous and differentiate among } m \text {-services } \\
\text { offerings on the basis of usage benefits }\end{array}$ & Supported \\
\hline $\begin{array}{l}\text { Hypothesis } 2 \mathrm{a} \text { : } \\
\text { Innovative attitude will be associated with intentions to use m-services }\end{array}$ & Supported \\
\hline $\begin{array}{l}\text { Hypothesis } 2 \mathrm{~b} \text { : } \\
\text { Mobile self-efficacy (techno-confidence) will be associated with intentions to } \\
\text { use m-services }\end{array}$ & Partially supported \\
\hline $\begin{array}{l}\text { Hypothesis 2c: } \\
\text { Love of shopping will be associated with intentions to use m-services }\end{array}$ & Partially supported \\
\hline $\begin{array}{l}\text { Hypothesis } 2 \mathrm{~d} \text { : } \\
\text { Susceptibility to interpersonal influence will be associated with intentions } \\
\text { to use m-services }\end{array}$ & Supported \\
\hline $\begin{array}{l}\text { Hypothesis 2e: } \\
\text { Males will express higher intentions to use m-services than females }\end{array}$ & Partially supported \\
\hline $\begin{array}{l}\text { Hypothesis } 2 \mathrm{f} \text { : } \\
\text { Age will be negatively associated with intentions to use m-services }\end{array}$ & Not supported \\
\hline
\end{tabular}

communication services, such as pictures, SMS and MMS. These consumers frequently ask friends for advice and intend to use the communication services MLE to allow them to consult friends and significant others. This trait is also associated, at a lower level of significance $(p>0.05)$, with the use of value-added shopping services.

\section{Gender}

This was found to be a statistically significant factor in relation to the intention to use only one of the MLEs: sports/entertainment services. On examination of the range of $\mathrm{m}$-services which load on this MLE, the strongly gendered nature of the relationship fits the expected stereotype of men's preferences for sports, online gaming, adult entertainment and online betting.

\section{Age}

This was not found to be associated with intentions to use any MLEs.

\section{Summary}

Table 6 shows that three hypotheses were supported (1,2a and $2 \mathrm{~d})$, three were partially supported ( $2 \mathrm{~b}, 2 \mathrm{c}$ and $2 \mathrm{e})$ and one was not supported (2f). As identified earlier, support for hypothesis 1 shows that consumers perceive $\mathrm{m}$-services as heterogeneous. For hypotheses $2 \mathrm{a}-\mathrm{f}$, innovators and belonging seekers are the key consumer traits that are associated with intentions to use all MLEs. The trait of being a shopping lover is also important in terms of likely use of MLEs, apart from sports and entertainment services. In terms of the demographic variables assessed here, only gender showed a positive association with intention to use MLEs.

\section{DISCUSSION}

This paper argues that while there is a vast range of $\mathrm{m}$-services, both existing and emerging, consumers are seeking specific bundles of usage benefits from $\mathrm{m}$-services. Moreover, it argues that these usage benefit bundles are associated with 
attitudinal and value orientations as well as demographic characteristics. Using factor analysis, $\mathrm{m}$-service typologies were empirically derived and identified as relating to distinct usage benefit types labelled MLEs — locator/information services, messaging services, sports/entertainment services, mobile online 'chat' services, value-added shopping services and financial services. It has also established, using correlation analysis, a strong pattern of associations between the attitudinal and value orientations innovators and belonging seekers and the intentions to use all MLEs.

By examining intentions to use $\mathrm{m}$-services, it has been established that, while mobile phones themselves may become ubiquitous and homogenous, there is a heterogeneous pattern in the variety of $\mathrm{m}$-service usage intentions. As consumers become more immersed in the use of their mobile devices and incorporate them into their daily lives, they perceive and construct benefits from the initial $\mathrm{m}$-services offerings and begin to organise them in ways that enhance their mobile life. In this research, clear patterns of benefit bundles of $\mathrm{m}$-services that add value to consumer mobile life were identified. For example, factor analysis revealed that locator/information services incorporating $\mathrm{m}$-services that enable consumers (and others) to know where they are physically located in the world and to know what is happening in the world were bundled together. Messaging services, incorporating SMS, MMS, pictures and reminders were also bundled together, as were financial services such as advanced banking, sending insurance damage reports, trading stock, making micro-payments and buying products online. These patterns provide valuable insights to help marketers to understand the meaningful relationships that consumers are developing among the fragmented and random services continually being introduced.

This research suggests that differences in consumer characteristics relating to values and attitudes will be associated with intentions to use particular life enhancing m-services. Those consumers who have high innovativeness traits are able to imagine novel ways to use their $\mathrm{m}$-services and to integrate new $\mathrm{m}$-services into existing patterns of mobile usage behaviour and life style. Moreover, they are able to develop new possibilities that product/service developers may not have initially envisaged.

As a result of the nature of $\mathrm{m}$-services, characterised by the rapid introduction of product/service extensions, the innovative consumer is likely to continue to be an important target market in two ways: first, for the uptake and diffusion of new m-services; and, secondly, for innovative appropriation of $\mathrm{m}$-services that enhance their daily mobile life. The authors' findings support those of Ridgeway and Price ${ }^{46}$ and Carroll ${ }^{47}$ who argue the importance of use innovativeness and the processes of technology appropriation.

Results showed that those who were excited by shopping were also significantly predisposed to the likelihood of using a wide of range of m-services. Techno-confidence, or mobile self-efficacy, was found to be significantly associated with the likelihood of using services high in informational content. It can be argued that techno-confidence or perceived mobile self-efficacy is associated with complex services requiring a more sophisticated use of mobile devices.

A further mobile consumer trait of seeking opinions from friends and others (consulters) is strongly associated with the likely use of mobile messaging services, which includes sending and receiving 
pictures, SMS and MMS. Given the propensity of this group to gather information from family and friends, their need to use this type of $m$-service is highly plausible. In addition, consumers with this trait show a significant inclination towards Value-added Shopping Services, such as receiving coupons, personal alerts and product information, which complements their need to consult others.

Finally, gender was considered in relation to $\mathrm{m}$-services and results show that males are significantly more likely to receive sports information, access adult entertainment, place bets online and play online games than females. No other demographic characteristics show significant association with likely usage of different types of m-services.

\section{CONCLUSION AND IMPLICATIONS}

The importance of affiliation and belonging in the use of $\mathrm{m}$-services affirms that the social network, peer bonding and celebrity endorsement strategies that were effective in building the market for the mobile phone handset are also highly likely to be effective in building the product extension market for $\mathrm{m}$-services. Peer to peer and viral marketing strategies are also likely to be particularly effective in this context. The strong element of visibility in use that facilitated adoption of the mobile handset should also be used to facilitate the adoption of $\mathrm{m}$-services. Public situations like sporting events, concerts and television programmes with high interactive programme components, all provide opportunities to model the use of $\mathrm{m}$-services and spread adoption in social networks.

The strong appeal to innovators across the whole $\mathrm{m}$-services typology is notable. Traditionally the new product adoption paradigm suggests that consumer innovativeness becomes less important as the product matures. As new m-services are constantly being developed and appearing in the market, however, it is likely that innovators will continue to constitute the core consumers of $\mathrm{m}$-services. It is also significant that there is no difference between those who feel confident with new technology and those who do not in the use of mobile online 'chat' services, such as sending e-mail and chatting online. This suggests that consumers are transferring the skills and competence established at their desktop computer directly to the mobile environment.

Marketers who already have established database information on consumer characteristics, such as innovativeness, belonging seekers, consulters and the love of shopping, should be able to use this knowledge to develop and build further the market for m-service product extensions. Similarly, the specific gender differences in the emerging uses of $\mathrm{m}$-services for sports and entertainment applications is likely to provide marketers with an increased ability to specifically target male consumers.

The adoption of the consumer perspective has resulted in a fruitful expansion of knowledge and understanding of $\mathrm{m}$-commerce drivers. Identification of the MLEs typology may provide a sound basis in which to manage existing m-services as well as developing and positioning new $\mathrm{m}$-services. In addition, the nexus between the MLE types and consumer values and attitudes further highlights the utility of adopting the consumer perspective.

\section{LIMITATIONS AND DIRECTIONS FOR FUTURE RESEARCH}

This study is not without its limitations. Although the descriptive statistics suggest that the snowballing method produced a 
usable sample of mobile phone users, the results must be interpreted with some caution. When future research is undertaken, a larger random sample should be used to improve representativeness. In addition, a number of substantive issues that arise from this study provide directions for future research. First, there is the need to more fully understand 'mobile life' with regard to such aspects as the freedom from physical location ties while desiring to be embedded in an informational net, the integration into virtual social networks and the need for continuous real time communication and consultation with significant others and the overlap of real and virtual roles.

Researchers should further explore the nexus between usage variety and social factors, such as social actions, social relationships and social roles related to MLEs such as communication and mobile online services. ${ }^{48}$ Finally, while penetration of mobile devices is nearly complete in many country markets, more research on $\mathrm{m}$-services usage intensity and usage breadth in combination with the usage variety explored in this paper is needed. Such research would enable researchers to refine their understanding of $\mathrm{m}$-service usage patterns in different country markets.

\section{References}

1 Analytics, S. (2004) 'US Sales of Handheld Devices', 1999 to 2003, epaynews, http://www.epaynews.com/statistics/ mcommstats.html last accessed 18 January 2004.

2 Juniper Research. (2004). Global mcommerce revenue projections for 2009 epaynews (Vol. 2004), http://www.epaynews.com/statistics/ mcommstats. html last accessed 8 September 2004.

3 Sullivan Mort, G and Drennan, J. (2002) 'Mobile digital technology: Emerging issues for marketing', The Journal of Database Marketing, Vol. 10, No. 1, pp. 9-24.

4 Pura, M. (2003) 'Linking perceived value of and loyalty to mobile services', in 'Proceedings of
ANZMAC conference' held on December 1-3, 2003; Adelaide, Australia, pp. 560-575.

5 Sullivan Mort and Drennan (2002) op. cit.

6 Chua, X. (2003) 'M-services: Consumer expectations of mobile self-service technology', Unpublished Honours Dissertation, University of Queensland, Australia.

7 Bertele, U., Rangone, A. and Renga, F. (2002) 'Mobile internet: An empirical study of B2C wap applications in Italy', Electronic Markets, Vol. 12, No. 1, pp. 27-37.

8 Sheth, J. N., Newman, B. I. and Gross, B. L. (1991) 'Why we buy what we buy: A theory of consumption values', Journal of Business Research, Vol. 22, pp. 159-170.

9 Anckar, B. and D’Incau, D. (2002) 'Value creation in mobile commerce: Findings from a consumer survey', Journal of Information Technology Theory and Application, Vol. 4, No. 1, pp. 43-64.

10 Kalakota, R and Whinston, A. (1997) 'Electronic commerce. A manager's guide', Addison-Wesley, Reading, MA.

11 Clarke III, I. (2001) 'Emerging value propositions for m-commerce', Journal of Business Strategies, Vol. 18, No. 2, pp. 133-148.

12 Pura (2003) op. cit.

13 Pura (2003) ibid.

14 Rodgers, S. and Sheldon, K. (2002) 'An improved way to characterize internet users', Journal of Advertising Research, Vol. 42, No. 5, pp. 85-94.

15 Anckar and D'Incau (2002) op. cit.

16 Rogers and Sheldon (2002) op. cit.

17 Mitra, K., Michelle, C. R. and Capella, L. M. (1999) 'An examination of perceived risk, information search and behavioral intentions in search, experience and credence services', The Journal of Services Marketing, Vol. 13, No. 3, pp. 208-228.

18 Nabih, M., Bloem, J. G. and Poiesz, T. B. (1997) 'Conceptual issues in the study of innovation adoption behavior', Advances in Consumer Research, Vol. 24, pp. 190-196.

19 Ridgeway, N. M. and Price, L. L. (1994) 'Exploration in product usage: A model of use innovativeness', Psychology and Marketing, Vol. 11, No. 1, pp. 69-75.

20 Carroll, J. (2004) 'Examining technology acceptance: When use involves more than intentions', in: School of Business and Information Management, Seminar, held at Australian National University, Canberra, Australia.

21 Rogers and Sheldon (2002) op. cit.

22 Donthu, N. and Garcia, A. (1999) 'The internet shopper', Journal of Advertising Research, Vol. 39, No. 3, pp. 52-58.

23 Agarwal, R. and Prasad, J. (1997) 'The role of innovation characteristics and perceived voluntariness in the acceptance of information technologies', Decision Sciences, Vol. 28, No. 3, pp. $557-582$. 
24 Wood, R. E. and Bandura, A. (1989) 'Impact of conceptions of ability on self-regulatory mechanisms and complex decision making', Journal of Personality and Social Psychology, Vol. 56, p. 408.

25 Compeau, D. R. and Higgins, C. A. (1995) 'Computer self-efficacy: Development of a measure and initial test', MIS Quarterly, Vol. 19, No. 2, p. 192.

26 Donthu and Garcia (1999) op. cit.

27 Bellenger, D. N. and Korgaonkar, P. K. (1980) 'Profiling the recreational shopper', Journal of Retailing, Vol. 56, No. 4, pp. 77-92.

28 Katz, E. and Lazarsfeld, P. F. (1955) 'Personal influence: The part played by people in the flow of mass communications', Free Press, New York, NY.

29 McGuire, W. J. (1968) 'Personality and susceptibility to social influence', in: Borgatta, E. F. and Lambert, W. W. (eds.), 'Handbook of personality theory and research', Rand McNally, Chicago, IL, pp. 1130-1187.

30 Bearden, W. O., Netemeyer, R. G. and Teel, J. E. (1989) 'Measurement of consumer susceptibility to interpersonal influence', Journal of Consumer Research, Vol. 5, pp. 473-481.

31 Teo, T. S. H., Lim, V. K. G. and Lai, R. Y. C. (1999) 'Intrinsic and extrinsic motivation in internet usage', Omega, Vol. 27, No. 1, pp. 25-37.

32 Gefen, D. and Straub Detmar, W. (1997) 'Gender differences in the perception and use of e-mail: An extension to the technology acceptance model', MIS Quarterly, Vol. Dec, pp. 389-400.

33 Anchnar and D'Incau (2002) op cit.

34 Teo et al. (1999) op. cit.

35 Bryman, A. and Cramer, D. (2001) 'Quantitative data analysis with SPSS Release 10 for windows:
A guide for social scientists', Routledge, London, UK.

36 Comfrey, A. L. and Lee, H. B. (1992) 'A first course in factor analysis', Lawrence Erlbaum Associates, Hillsdale, NJ.

37 Schillewaert, S., Langerak, F. and Duhamel, T. (1998) 'Non-probability sampling for www surveys: A comparison of methods', in: 'Proceedings from the 27th EMAC Conference', held in Stockholm, May, 1998.

38 Comley, P. (1996) 'The use of the internet as a data collection method', in 'Proceedings of ESOMAR/EMAC Symposium', held in Edinburgh, Scotland, November, 1996.

39 Bearden et al. (1989) op. cit.

40 Conway, J. M. and Huffcutt, A. (2003) 'A review and analysis of exploratory factor analysis practices in organizational research', Organizational Research Methods, Vol. 6, No. 2, p. 150.

41 Conway and Hoffcutt (2003) ibid. pp. 147-168.

42 Thurstone, L. L. (1947) 'Multiple factor analysis: A development and expansion of the vectors of mind', University of Chicago Press, Chicago, IL.

43 Gorsuch, R. L. (1997) 'Exploratory factor analysis: Its role in item analysis', Journal of Personality Assessment, Vol. 68, pp. 532-560.

44 Tabachnick, B. G. and Fidell, L. S. (2001) 'Using multivariate statistics', Allyn and Bacon, Needham Heights, MA.

45 Tabachnick and Fidell (2003) ibid.

46 Ridgeway and Price (1994) op. cit.

47 Carroll (2004) op. cit.

48 Geser, H. (2004) 'Towards a sociological theory of the mobile phone', Sociology of Switzerland Online Publications, University of Zurich, Zurich, Switzerland, http://socio.ch/mobile/tngeserl.htm last accessed 18 October 2004. 